\title{
Understanding People and Technology. Professional Military Education and Challenges of Future Commanders Development
}

\author{
Eugeniusz CIEŚLAK
}

\author{
Institute of Social Sciences and Security, Faculty of Humanities, Siedlce University of Natural \\ Sciences and Humanities, 39 Żytnia st., \\ 08-110 Siedlce, Poland \\ E-mail: eugeniusz.cieslak@uph.edu.pl
}

\begin{abstract}
Significant changes to security environment make military operations more complex and demanding. Preparing military commanders to face future challenges has been vital for military success and national security. While the system of the Professional Military Education seems good, there are opportunities to make it more responsive and efficient. The article summarizes the ongoing discussion on the Professional Military Education, and identifies challenges related to preparation of future commanders. Based on recent developments some ideas on improving Professional Military Education are offered.
\end{abstract}

KEY WORDS: Professional Military Education (PME), social dimension, new technologies, military operations, commanders

\section{Introduction}

The security environment evolves rapidly and employment of military power becomes more and more complex. Military commanders face compressed battle space and levels of warfare and act in complex social, cultural and economic environment. Despite the level of command and control, all future military commander require comprehensive knowledge stretching out of typical military toolbox to be effective in achieving objectives of a broad scope of military operations. Technology becomes one of the most rapidly changing aspects of security environment. It is especially true for emerging and readily available technologies with military relevance that may be available even to non-state actors. All that requires diligent efforts to prepare future commanders for making decisions and acting in intertwined social and technological scenarios. Understanding people and technology seems a prerequisite for success, while not understanding even one of those aspects may be disastrous. Lessons learned from military operations just in recent decades prove the value of comprehension of both social and technological dimensions of security environment.

Depending on the level of command and control as well as a type of military operations future commanders will need different mix of social and technological expertise. Professional Military Education offers unique opportunities for future commanders to grow intellectually, reflect and anticipate changes in security environments. Case studies serve as a way to improve future commanders' skills to act in complex environments. Along with introduction to theoretical approaches to decision making under certainties and simulation and modelling, case studies proved to be effective in preparing commanders for operations in complex environments.

\section{Ongoing Discussion on the Professional Military Education}

The Report of the Panel on Military Education appointed by the Armed Forces Committee of the House of Representatives of the US Congress is for many reasons an extremely valuable analytical study on the Professional Military Education. Since it was published on April 3, 1989, it has been setting the stage for further discussions on developing future commanders and provides clear benchmark to proposals related to Professional Military Education nowadays. The so called Skelton Report offered broad scope of analyzes and assessments of officers' command and staff education and recommended changes in the education and training of officers, which translated into practical solutions in US military education and influenced similar solutions in other Western countries. In 2010, the U.S. Congress published a follow-on report that attempted to assess the extent of changes that took place as a result of the 1989 recommendations. For those interested in the professional development of officers it may be interesting that there were numerous problems that could not have been solved and some of the recommendations of the Skelton Report proved to be more difficult to

Corresponding author.

E-mail address: eugeniusz.cieslak@uph.edu.pl 
implement than it seemed back in the eighties. A significant part of the observations contained in the Skelton Report is universal and remains valid after almost thirty years inspiring stormy discussions and fierce disputes over the education and training of officers in American political, military and academic environments. They influence also professional discussions related to Professional Military Education in other countries.

Work on the Skelton Report began in November 1987. The panel for military education was to check whether the existing command and staff education and training system allows harmonized training of officers for the needs of particular types of armed forces and joint forces. The panel was also supposed to assess the ability of the Defense Department's military education system to develop professional military strategists, joint warfighters and tacticians. An additional area of work, was the quality of military education and training of officers, which was considered to be crucial for the effectiveness of teaching the problems of strategies and operations of joint forces. Although in the general assessment of the panel, the defense education system of the Defense Department was considered good and the schools were fully comparable with the most prestigious military universities in Europe, it was recognized that a significant improvement in the existing situation could and should be made. The panel proposed specific recommendations regarding various aspects of officers' command and staff education and training. From the perspective of more than a quarter of century, it is not so much a literal familiarization with particular recommendations as the analysis and understanding of the arguments used by the panel when proposing individual conclusions and postulates. The Skelton Report advocated precise delimitation of the content of education programs at particular teaching levels and to standardization of the essential elements of education programs in schools of all services of armed forces in such a way that it would be possible for officers to study in the other services' schools. Skelton's panel proposed that the education and training of command and staff officers for the needs of the joint forces should be divided into two stages. In the first stage, in schools for middle-level officers of different types of armed forces (service intermediate college), all students were to learn about operational capabilities and limitations of particular types of armed forces, command of particular types of armed forces, doctrines and organizational concepts, as well as the planning process in connected forces. In the second stage, the officers envisaged to take positions in headquarters, staffs and joint institutions, were to educate themselves in the scope of the doctrine of joint forces and to conduct analyzes of possible operational scenarios. An important element of the second stage was to strive for a better one concerning the issue of training officers.

In addition to the activities allowing for greater freedom to recruit and reward civil teachers, it was postulated that only the best officers would be lecturers at the command and staff schools, with a clear prospect of further promotion, knowledgeable in a specific specialty, and academic education. Interestingly, the need to graduate stationary command and staff studies at the level at which they will teach would be emphasized. The quality of education was to be improved also thanks to the tightening of didactic rigors for students. The report recommended introduction of the systematic requirement for students to prepare written assignments, exams, essays and other studies. Writing was to increase the students' skills in the field of developing various types of documents, formulating conclusions and assessments, and arguing. Teaching staff had to study the students writings thoroughly, criticize their content and assess it [1]. The Skelton Report had a significant influence on the command and staff training of the officers of the American armed forces. The recommendations of the Congress led to clear changes in the education philosophy of commanders and staff officers, unification of approaches in particular types of armed forces to the content of teaching and the introduction of didactic rigors. Clearly, from the perspective of more than two decades, the quality of command and staff training has increased.

In April 2010 the Committee of the Armed Forces of the House of Representatives of the US Congress published "The Another Crossroads report? Professional Military Education Two Decades After the Goldwater-Nichols Act and the Skelton Panel", in which it assessed the implementation of its recommendations and the PME in the U.S. Armed Forces. The scope of analyzes and evaluations made for the needs of the report was significantly smaller than the work related to the Skelton Report. However; the authors formulated a number of conclusions referring directly to the improvement of Professional Military Education [2]. For people involved in the professional education and training of officers, there may be some interesting themes in the 2010 report. The first one, concerning these aspects of education, which were improved as a result of the Skelton panel's work. The second one, which describes the difficulties and failures in improving the PME of the American armed forces. The 2010 report conclusions considered that the officers' PME system was basically good, but some of its elements needed improvement. The introduction of solutions and didactic rigors ensuring the quality of education was recognized as an unambiguous success. The flexibility and adaptability of officers' PME were positively assessed. The general philosophy of officers' command and staff education and training has evolved along with dynamic changes in the security environment and changing operational needs. The scope of the training content of junior officers has been extended, which are currently being prepared for activities in the framework of combined forces and senior officers, who are more familiar with the problems of national security strategy to a greater extent than before. Despite the reactive nature of changes in education, both its content and form were adequate to the operational needs of the US armed forces.

Some of the problems in the implementation of the recommendations of the Skelton Report resulted from the intensity of the use of armed forces in military operations after the end of the Cold War, especially after the terrorist attacks of September 11, 2001. The simultaneous operations in Iraq and Afghanistan caused such a heavy burden that a significant number of officers had difficulties with participation in resident command and staff study programs. Increased staffing needs in both operations meant that some officers were assigned positions in commands and staffs without the required training and without some key skills necessary for proper performing duties on the positions held6. It should also be noted that at the same time many officers assessed that during the command and staff education and training, they were not properly prepared to take up staff positions. The 2010 report critically assessed the efforts of the Department of Defense and services of armed forces to prepare officers to able to function at strategic levels. It 
was assumed that the PME did not play essential role in shaping the professional development of officers envisaged to occupy key positions at the strategic levels in the future. The Committee of the Armed Forces of the House of Representatives of the US Congress assessed that the efforts of services and combatant commands in identifying and selecting officers predisposed to occupy positions at strategic levels and support their professional development were incoherent and not fully effective.

The 2010 report revealed that activities aimed at increasing the quality of the staff engaged in the PME turned out to be a half-successful ones. The problems related to the provision of high-quality teaching and managerial staff as well as students endured. Teaching in command and staff schools turned out to be not always attractive to officers with the greatest potential for professional development. All-too-long stay at the university reduced the officer's chances for promotion, while a rapid promotion and return to the line before the end of the three-year term as a lecturer did not allow full use of the officer's experience in didactics. The report also suggested to adopt more precisely defined criteria for appointing officers to managerial positions in the PME institutions and to extend them he term of assignment so that they could better understand the complexity of the command and staff education and, consequently, ensured stability in the PME institutions management. One of the aspects of the PME organization, which was highlighted in the 2010 report, was the selection of students. There was a differentiated approach of services in the field of personnel policy related to directing officers to full-time studies, which diversified the level of substantive competence between students in different universities.

The title of the report on the command and staff training from 2010 begins with the question "(if) "Another Crossroads?". After learning about its contents, one can risk answering "yes". Although the authors of the 2010 report did not recommend such radical changes as the Skelton panel did in 1989, they emphasized the need for constant care for the PME and decisions affecting the future of officers' education. The Skelton Report and the 2010 report were the only documents of the U.S. Congress devoted directly to the education and training of officers, despite the fact that the issue was important enough to merit more systematic and more frequent parliamentary oversight [2].

The language, conclusions and recommendations of both reports on the PME can be considered balanced and often even too restrained. The language of the public debate devoted to this problem is different, which may be seen on the pages of professional military and civilian periodicals in the USA. One of the most prominent voices in the American debate on the PME was the article of retired general Robert H. Scales "Too Busy to Learn" published in "Proceedings Magazine" in February 2010. A former commander of the Army War College, a recognized expert in the use of ground forces and a doctor of history, Scales risked the thesis that American forces do not pay sufficient attention to the intellectual development of officers, which may have negative consequences for future security [3]. Scales noted that, similarly to the experience of the British army in the second half of the nineteenth century, the involvement of the U.S. Armed Forces in small and easy wars led to negative changes in organizational culture. In his opinion, excessive preference for operational experience in personnel policy led in the land forces to the situation in which officers avoided taking part in command and staff studies, fewer and fewer officers were lecturers in such studies, and the duration of studies was significantly shortened. Scales accused the armed forces that they prefer acting at the expense of the intellect (action versus intellect) and do not pay sufficient attention to the PME. Importantly, Scales did not treat changes in military education as a "pedagogical" problem, but as "human". He believed that only when the personnel system would "reward" the intellectual development of officers, would the long-term development of armed forces be possible [3]. Recalling the changes initiated by the Skelton panel, Scales recommended investing in the intellectual development of officers in the early stages of their military career. He also pointed at the importance of humanistic education of officers, which will allow them to function better in diverse cultural environments. Scales explicitly advocated teaching by officers (and curbing teaching by "contractors"), college entrance examinations, and extorting knowledge of a foreign language as a condition for officers promotion. In his opinion, the individual PME assessments describing the intellectual achievements of the officers should be as important as the other official opinions and should have a measurable impact on their professional development.

Charles D. Allen, in the article "Redress of Professional Military Education", attempted to explain some of the problems raised by Scales. Allen, a retired colonel, a professor at Army War College, described the phenomenon of "new, normal". Intensive participation in operations accelerated obtaining higher military positions by the Army officers. It was also typical for the superiors to delay the direction of the best officers to resident command and staff studies, or even to justify non-participation in such studies due to operational needs [4]. Due to the needs of operations in Iraq and Afghanistan, officers and infantry officers in Army War College almost did not participate in command and staff studies. Allen suggested that the consequences of such an approach to command and staff education and training of officers would be felt in the future and manifest in inadequate preparation of officers occupying key positions in the armed forces and advising representatives of the government. Like General Scales, Allen sees problems related to the PME through the prism of organizational culture. Allen resembles the principle of the same approach to lifelong learning and professional development by the institution, commanders and individual officers enshrined in the development strategy of the leaders for the Army of the 21 st century. Everyone should equally care for the education of successors and their intellectual development. Allen also points to the staff aspect of the effectiveness of command and staff education and training of officers. Commanders should pay due attention to providing their subordinates with adequate education in a time allowing for its full use in their professional development. Allen concludes that if the path to the promotion (success) will run through the PME, and not bypass it, the system itself will be repaired [4].

The need to give more intellectual development to officers was indicated in the statements for the Committee of Armed Forces of the House of Representatives, by civilian and military specialists. One of its kind respondent was prof. 
Williamson Murray, who provided information to the Skelton panel members in 1987-1989, and then supported the work on the 2010 report. Prof. Murray observed that, unfortunately, most of his fears dating from a quarter of a century ago remained valid. The professor said that a thorough education is necessary for the preparation of senior officers to understand the nature of the war and its diverse contexts, and consequently for efficient functioning in a security environment. According to Murray, education of officers is a long-term investment in the future of the country, which is why services of armed forces should be willing to devote some of their short-term priorities to long-term activities aimed at intellectual development of officers. Professor Murray had no doubt that the success of the PME was entirely dependent on the fundamental reform of the staffing system and the promotion rules that would ensure the promotion of competent officers. Like General Scales, Murray proposed introducing entrance examinations to the command and staff schools, to radically change the anti-intellectual culture that characterizes many of the junior officers in the US Air Force. In the words of his speech, Murray appealed to Congress to give officers enough time to study, so that they would not be punished in their further career for spending time at school. In his recommendations he also stressed the need for "much more rather than in the past "selecting persons for managerial positions in military academies, suggesting that such positions should be assigned to persons with significant experience gained in operations and with serious academic references [5].

Retired general David W. Barno, in his statement to the Congress in 2009, pointed at the promotion of "muddy boots" bias. In his opinion, the unintended effect of preferring in the recent years the promotion of "action people" and not "people of reflection" will result in the next few years in a generation of generals fluent in tactics at positions requiring thinking in strategic terms. Barno also proposed increasing the PME of generals who in the last ten or fifteen years of service are engaged in solving more and more complex problems, but they do not have time to study and reflect [6]. In the recommendations for Congress, General Barno appealed to create an atmosphere of respect for military intellectualism, thinking soldiers (warriors) and thinking warriors (soldier warriors and soldier-scholars).

In the American discussion about the PME, the arguments about military anti-intellectualism, anachronism of the content taught, and post-commander-staff studies for too late a period in the officers' career were often made. Depending on the inclinations of political authors, it was postulated to train officers in the "free market" or only in military schools and only by the best officers. Regardless of the fundamental differences in views, participants in the public discussion underlined the importance of thorough and comprehensive education and training of officers as a guarantee of state security. Officers with wider intellectual horizons are considered in American political, military and academic environments as people who are able to make decisions and effectively operate in complex environmental conditions safety. Excessive favoritism, partly at the expense of Professional Military Education, of operational experience in the professional development of officers was considered potentially dangerous in a longer time horizon, when proficiency in tactics may prove insufficient to solve strategic problems.

\section{Challenges to Professional Military Education}

The challenges to the Professional Military Education and preparation of future commanders result from changes to security environment, to include new threats and requirements for employment of military forces in a growing spectrum of operations. Post-cold war military operations provide a lot of examples how complex security environment may be and how difficult it is to apply traditional tenets of war to new operational scenarios. The NATO involvement in peace support operations in the Western Balkans back in the nineties resulted in creating a separate part of allied joint doctrine focused solely on non-article V crisis response operations. New principles of such operations were named, among others, consent, perseverance, mutual respect and transparency. Most of them quite different from well known ones of surprise, economy of force or unity of effort. It must be understood that it takes time for organisations to learn. The bigger they are, the more hierarchic, the more difficult it is for them to adapt. The change in the nature of military threats immediately after the end of the Cold War resulted in wider use of armed forces in crisis response operations, which were then called military operations other than war. The operations of the UN and NATO in the Balkans, carried out in the nineties of the last century, and the actions of the UN and the U.S. forces in Somalia, made politicians and military officials understand how complicated it was to combine combat, stabilization and humanitarian activities in a single operation. Thus a term "the three block war" proposed by the USMC General Charles Krulak entered the military dictionary. Activities in Iraq and Afghanistan only confirmed the experience accumulated in the nineties of the last century. While the changing nature of military threats and operations resulted in adaptive changes in the doctrine, the development of information technologies has provoked a number of radical concepts and raised expectations that are difficult to meet. The belief in an almost unlimited access to information was reflected in the concepts of the network-centric warfare and effect based operations based. Those two examples offer good examples about possible challenge to the Professional Military Education as both revealed the complexity of understanding human and technological dimensions of military operations.

The origins of the network centric warfare dates back to 1998, when the article by Arthur K. Cebrowski and John J. Garstka "Network Centric Warfare: Its Origins and Future" was published. The network-centric warfare was supposed to be the response of the armed forces to the development of information technologies and the beginning of the information age in the civilian environment. Networking troops was hoped to increase combat capabilities of smaller, faster-acting, self-synchronizing, distributed military units, sensors and measures of kinetic and non-kinetic influence. Operations of networked forces was expected to result in fast concentration of effects, without the need for concentration of troops. As a consequence, the execution of combat tasks might require smaller forces, less logistic support, reducing the overall costs of military operations. The network centric warfare concept developed to include idea of knowledgeable force, which assumed 
that the networked military units would be able to better understand the implications of the changes in operational and tactical situation, the intentions of the commander in the same way and to conduct autonomous operations more easily [7]. The U.S. approach to the network-centric struggle made networking the central element of the concept of warfare affecting the fundamental changes in its nature. Such a radical approach has not been adopted in other countries or in the NATO as a whole. Although networking has been recognized as important for warfare, it is now considered one of the many capabilities affecting the way the armed forces operate. Examples include the British approach to network-enabled capability, the Australian concept of network-enabled warfare or the NATO Network Enabled Capabilities - NNEC. It is interesting to observe that the Professional Military Education was initially impressed by the ideas of the network centric warfare and it took some time for more critical views to reach future commanders' teaching environment. Over a decade of using network-centric solutions in military operations revealed a number of prosaic problems that can be caused by the implementation of network solutions. The network of sensors necessary for having an information advantage now provides so much data that it is almost impossible to analyze them in time. Sensor lifetime can be problematic in high-intensity conflict conditions. The availability of reconnaissance data has increased the military's expectations for the availability of image data in almost real time, which translated into the size of data transfer and the load on the command, control and communication network. It seems that no matter how much the data transmission capacity increases, the expectations of network users will increase even more, making it difficult to meet the call for network-centric access to high-quality information services. For that reason, the network centric warfare concept provides a good example on how to remain careful in putting new concepts in the Professional Military Education.

Another concept that influenced directly the preparation of future commanders was that of effect based operations (EBO). This concept had its origins in the network-centric struggle, and the first official publication describing it was published in 2001 by the US Combined Forces Command (USJFCOM). In essence, such operations were to be aimed at influencing the cognitive domain of the opponent and its individual components. Proponents of the concept argued that precise kinetic and non -kinetic actions were not so much to destroy the opponent's military forces, but to convince adversary political and military decision makers about the futility of further battle. The concept of effect based operations led to changes in planning. While traditionally the objectives of the operations were the basis in military planning, the results were to be found in the EBO. These results were divided into direct and indirect ones. Among the direct results, physical, functional and collateral effects were distinguished, among others. However, the typology of indirect results was slightly more complicated and included results: functional, side, psychological, systemic, cascade and cumulative. Additionally, in the planning of operations based on the expected results, it was assumed that the indirect results could be predicted and evaluated not only for first-order effects, but also the second, third and subsequent orders (which can be the consequences of the opponent's reaction to our forces, and then what further consequences of these consequences may be, etc.). Planning activities in accordance with the EBO methodology was to help find the answer to the question, what actions should be taken to achieve the desired changes in the behavior of the opponent in the tactical, operational and strategic dimension. If one takes into account that system-of-system analysis (SoSA) necessary to make operational decision making should include nodes and systemic ties in political, military, economic, social, infrastructure and information systems (PMESII), it is easy to understand the scale of challenges related to the implementation of the concept of effect based operations in the U.S. armed forces. About five years after the publication of the EBO concept, its implementation in the U.S. armed forces was at least controversial and sensitive. The concept was still not fully defined, its application in various combined headquarters differed significantly, and planning based on the expected results long-term engaged a significant number of specialists. In 2006, professor Milan N. Vego from Naval War College published the article "Effects-Based Operations: A Critique" in which he pointed at an excessively deterministic, even mathematically zero-one, approach of EBO supporters to war [8]. Australian officers, J. Kelly and D. Kilcullen, also argued that the use of mathematical methods to measure non-measurable effects of the second or third order (eg in the social system) is at least problematic and it is difficult to expect that the EBO will reduce the basic the uncertainty associated with conducting military operations [9].

Disappointment in the US armed forces with the concept of effect based operations led to the publication in 2008 the memorandum of the U.S. JFCOM, General J. N. Mattis assessing such operations. Mattis expressed his conviction that the diverse interpretations of the EBO concept have created confusion both in the US armed forces and among the U.S. allies. In his opinion, the concept of EBO began to be misapplied and created more harm than help to operations. Mattis called for a return to historically proven principles and terminology, which could be understood by all involved: the commander's intention, unambiguous tasks and achievable ends. It should be noted however that Mattis did not condemn the whole concept and pointed to the usefulness of some analytical concepts related to EBO to some elements of planning activities with regard to the so-called closed systems [10]. So what's the linkage between the Professional Military Education and the preparation of future commanders and the effect based operations concept? First and the most important is to keep new concepts in touch with real world observations. The real life has as much to say as new concepts do. If new concepts do not translate into better operations, it's probably better rethink those concepts. Another point is the complexity of teaching. It is unrealistic to assume that all future commanders will be men of reflection with broad knowledge stretching out of military expertise. So the Professional Military Education should find a way to teach complex issues in a way that allow understanding them by a wider audiences, not only small elites.

The armed forces for which the concept of EBO turned out to be the most harmful, were the Israeli self-defense forces. Assuming that the actions of a potential enemy may be paralyzed as a result of precise air and missile strikes on its key military objects, less attention was paid to the development of tactics for land operations. Israeli methodology of systemic operational planning (Systemic Operational Design - SOD) was to encourage commanders to critical, systematic and methodological thinking about warfare and give them tools to conceptualize both the opponent and own forces by 
designing appropriate campaigns. The creator of the SOD, General Naveh, believed that his innovative methodology would allow commanders using creativity, experience, intuition and assessment skills to develop detailed operational plans. Israel's war with Hezbollah in 2006 showed, however; something quite different. There were a number of reasons for the failure in implementing the Naveh's methodology. The terminology used in the SOD came from postmodern French philosophy, literary theory, architecture and psychology. The new terminology and methodology of conduct and the complexity of the approach, which Naveh described as "not intended for ordinary mortals", meant that a significant proportion of the Israeli officers did not understand why simple and understandable command and control procedures was replaced by a methodology that only a few of them could understand. Adopted in April 2006 for use in the armed forces of Israel, the new doctrine was largely based on Naveh's methodology, and the boundaries between EBO and SOD were not precisely defined. Israeli military theorist, retired officer, Ron Tira, noted that of the 170 pages of the new doctrine many experienced officers did not understand more than half, and the terms used in it were so imprecise and ambiguous that it was difficult to plan and conduct combat operations on their basis [11]. Thus, one may see the risks associated with the attempts of turning not fully proven concepts into standard operating procedures. While those concepts would beneficial in classroom environment in many PME programs, they turned out not to be suitable for tactical level decision making.

Nowadays, the situation seems even more challenging than just a decade ago. Technology becomes one of the most rapidly changing aspects of security environment. If one thinks about information operations the cyber attacks are no longer the most dangerous threat as we are better and better prepared to deal with them. Smartphones and social media have become much more powerful tools of influencing society and military opinions. No bullet is as fast as a tweet, no weapon reaches more "victims" that Facebook. Future military commanders need to be aware of that and stay one step ahead of possible adversaries. But; is it realistic? One may point to another phenomenon of emerging and readily available technologies with military relevance. Unmanned remotely controlled vehicles used to be for a long time available to advanced militaries. Right now they are readily available to non-state actors and even individuals. What's more non-state actors are more open to experimentations with new technologies and not bound by rigid planning and financing mechanisms typical for armed forces. Such situation challenges long-term assumption held by military. Non-state actors no longer are those weaker ones, with lack of advanced weapons, doomed for defeat. Cheap weapons available to non-state actors may be technologically advanced enough to fight regular military forces in efficient way. Israel fighting Hezbollah in 2006 experienced that and recent operations in Syria show employment of unmanned aerial vehicles as a hallmark of non state actors activities. At some point it may be difficult to predict what of civilian technology may be used as a weapon and with what effect. To paraphrase Donald Rumsfeld, with nanotechnology at the corner, we are approaching a security environment not only of "known and unknown knowns", but with a wide spectrum of unknown unknowns. Human dimension of future security environment requires as much attention as emerging technologies. As Western militaries engage in a number of crisis response operations worldwide we need to put more attention to human side of conflict. It is necessary to understand what makes people fight and what is necessary to make long lasting peace. The difference in cultural values is obvious not only for far away societies, but it is present here and now inside the NATO and the European Union. Most uneasy to observe is the lack of common values between the Russian Federation and the Western community. For the future commanders it is absolute must to understand both adversaries and allies and that's why Professional Military Education matters.

\section{Possible Improvements to the Professional Military Education}

Professional Military Education along with specialized military training and professional, including combat, experience will remain crucial for developing future commanders to meet challenges of evolving security environment. Although the current set up of Professional Military Education in Western militaries seem sound and generally effective; nevertheless there are some areas that require more attention and there are opportunities for improvement of existing solutions. One of the most basic questions related to development of future commanders is what to teach, when to teach and whom to teach. As the development path for future commanders starts typically with majority of specialized training and focuses on tactical level, the comprehension of operational and strategic aspects of warfare comes later - usually for field grade officers and then senior officers. The change in the nature of threats and growing spectrum of military operations make such an approach not fully compatible with requirements of developing future commanders. While Professional Military Education for officer candidates and junior officers should remain focused on tactical level it need to include also at least introductory modules stretching into operational and strategic dimensions of employment of military power. Taking into account that tactical actions and decisions by junior officers may result in operational and even strategic consequences, it is worth investing some period of Professional Military Education to make them familiar with some of facets of security environment they will operate in. To put it simple, it makes sense to show junior officers future commanders how intertwined, contested and dynamic is the security environment, how little dot on that picture are their actions, and finally how important they are to the overall success of the operations. Similarly to findings of Skelton and 2010 reports, there is a growing need to prepare officers earlier in their careers to operate in international, culturally diverse, environments, to make them aware of operational and strategic consequences of their actions or inactions, and finally not to scare them with growing responsibility of command.

Understanding people and technology at the same time by future commanders should be instilled at every level of Professional Military Education. There are different approaches to developing social and technological competences of future commanders. For those who will remain "operators" and not "technicians" it is important to know what can technology provide and what limitations it has in military applications. With the use of simulation and modelling during Professional Military Education; it is possible to raise awareness of future commanders about technological aspects of 
future security environment. Typically, modelling and simulations should be "eye - opener" by giving future commanders non-negotiable reference figures and calculations about operational performance, logistic support requirements or forcetime-space calculations. As important as above would be to reveal consequences of miscalculations of technological aspects of military operations. For the younger generation of officers it is quite common to adopt simplified assessment of technology. One smart bomb seems enough for every target, Power Point presentation fidelity seems precise enough, etc. More complex assessments related to combat and combat service support requirements offered thanks to modelling and simulation may be beneficial to future commanders. Because of that a carefully tailored package of modelling and simulation should be a part of Professional Military Education at every step of future commanders professional development. Use of "technology watch" should not be hesitated to keep future commanders aware of technology development that may impact security environment.

Developing social skills of future commanders requires more focus on human aspects of security environment. A careful selection and use of case studies will be helpful in preparation of future commanders to understand people better. Possible improvements in using case studies should be sought in selection of such cases, and then in using them to reinforce another elements of Professional Military Education. The ongoing operations or those conducted by the NATO in recent decades should be studied in details. It would be beneficial to future commanders to be exposed to the complexity of factors that influenced international community involvement in the Western Balkans, Afghanistan and Libya. Comprehension of competing objectives, national perspectives on specific courses of action, complexity of logistic support or local community attitude toward allied troops, may improve the quality of future commanders' preparation through the Professional Military Education. Studying military history remains vital element of preparing future commanders. The point is to study more this part of recent military history that may be useful in ongoing operations and to capitalize on lessons learned not hundred years ago, but during recent decade, in similar operating conditions.

Finally, political and military decision makers should resist the temptation to limit the Professional Military Education as a part of future commanders development. While favouring operational experience may accelerate individual officer's professional development, in long term it may decrease strategic thinking skills at the military top levels. One should avoid treating military education and training interchangeably. The Professional Military Education constitutes a critical component of developing future commanders because it prepares them for uncertainty that will remain a characteristic feature of future security environment [12]. It is education that gives future commanders a broad base of knowledge and develops their critical thinking skills. All necessary to make proper decisions and act wisely in not fully predictable situations. Military specialized training will not hone such skills of future commanders; although it will prepare them for known tasks.

\section{Conclusions}

The dynamic changes to security environment observed in recent decades influenced significantly employment of military power. Military commanders make decisions and act in compressed battle space not bound by traditional levels of warfare. Military operations are conducted in complex social, cultural and economic environment. Future commanders will require comprehensive knowledge to be effective in a broad spectrum of military operations. Two dimensions of future security environment seem to be the most important ones to preparation of future commanders: technology and human dimension of armed conflict. Technology changes security environment and redefines what's possible in military operations. But there are more and more emerging and readily available technologies with military relevance that are available to non-state actors. All that requires future commanders to be prepared to make decisions and act taking into account intertwined social and technological factors. Understanding people and technology seems a prerequisite for success of future commanders. Use of modelling and simulation along with applying case studies during the Professional Military Education programs are just examples of tools to improve technological and social skills of future commanders. Changes to security environment should result in the evolution of the Professional Military Education and some of the anticipated changes should even shape curricula and teaching content. To assure the quality of future commanders development proper support to the Professional Military Education is needed. It should be treated as an investment in future commanders that will pay back in increased national security.

\section{References}

1. Comittee On Armed Services House of Representatives Report of the Panel on Military Education of The One Hundredth Congress of the Comittee On Armed Services House of Representatives One Hundred First Congress First Session, April 21, 1989. U.S. Government Printing Office, Washington 1989, p. 13, 165

2. Committee on Armed Services, Subcommittee on Oversight \& Investigation Another Crossroads? Professional Military Education Two Decades After the Goldwater-Nichols Act and the Skelton Panel, Committee Print 111-4, April 2010, p. XI, XIV, 34-36

3. Scales R. H. Too busy to Learn in Proceedings Magazine February, 2010, Vol. 136/2/1, no pagination

4. Allen C. D. Redress of Professional Military Education. The Clarion Call in Joint Force Quarterly, 2010, Issue 59, p. 97-100

5. Murray W. Testimony. House Armed Services Committee, Subcommittee on Professional Military Education, not 
dated

6. Barno D. W. Testimony. House of Armed Services Subcommittee on Investigations and Oversight, September 10, 2009, no pagination

7. Cebrowski A. K., Garstka J. J. Network Centric Warfare: Its Origins and Future in Proceedings Magazine, January 1998, Volume 124/1/1139, p. 35

8. Vego M. N. Effects-Based Operations: A Critique in Joint Force Quarterly”, Issue 41, 2d Quarter 2006, p. 54

9. Kelly J., Kilcullen D. Chaos Versus Predictability: A Critique of Effects-Based Operations in Security Challenges, Volume 2 Numer 1, 2006, p. 97

10. Commander U.S. Joint Force Command. U.S. JFCOM Commander's Guidance for Effects-Based Operations, Norfolk, 14 August 2008

11. Matthews M. M. We Were Caught Unprepared: The Hezbollah - Israeli War 2006, U.S. Army Combined Arms Center, Combat Studies Institute Press, Fort Leavenworth, Kansas 2006, pp. 24 - 25

12. Cieślak E. Raport Skeltona a kształcenie dowódczo-sztabowe oficerów. Nowa Bellona 4, 2013, p. 186-198 